\title{
PENYULUHAN DAN PELATIHAN PEMBUATAN LAPORAN PENELITIAN TINDAKAN KELAS BAGI GURU SEJARAH SEKOLAH MENENGAH ATAS DI PALEMBANG
}

\author{
Muhammad Reza Pahlevi, Hudaidah* \\ hudaidah20@gmail.com \\ Prodi Pendidikan Sejarah, Fakultas Keguruan dan IImu Pendidikan Universitas Sriwijaya \\ Diterima 20 November 2019, Diterbitkan 30 April 2020.
}

\begin{abstract}
Abstrak
Persoalan mengenai bagaimana meningkatkan kompetensi guru masih menjadi tantangan besar bagi dunia pendidikan saat ini. Salah satu cara untuk meningkatkan kinerja guru adalah melalui Penelitian Tindakan Kelas (PTK). Dari hasil studi pendahuluan yang dilakukan tim PPM dengan beberapa alumni Prodi Pendidikan Sejarah FKIP Unsri yang telah menjadi tenaga pendidik di Kota Palembang melalui wawancara, diperoleh informasi bahwa mayoritas guru belum memiliki pemahaman yang mendalam tentang bagaimana membuat laporan PTK yang benar. Maka dari itu, sebagai bagian dari Pengabdian Kepada Masyarakat, Prodi Pendidikan Sejarah FKIP menyelenggarakan Penyuluhan dan Pelatihan Pembuatan Laporan PTK Bagi Guru Sejarah SMA di Kota Palembang. Hasil dari kegiatan tersebut adalah, pertama kegiatan pelatihan dan penyuluhan berjalan dengan baik oleh tim. Kedua, para peserta kegiatan sudah mendapatkan gambaran yang jelas mengenai penyusunan laporan PTK melalui workshop yang telah dilakukan. Ketiga, dengan hasil yang didapat, para peserta diharapkan menjadi guru yang kompeten dan inovatif dalam pembelajaran di kelas.
\end{abstract}

Kata Kunci: Pelatihan PTK, Guru Sejarah, Sekolah Menengah Atas di Kota

\section{PENDAHULUAN}

Pembelajaran Sejarah tidak jarang dikesankan membosankan oleh sejumlah peserta didik, karena dianggap hanya mengajarkan hapalan segudang peristiwa bersejarah, baik nama peristiwa, para pelaku, waktu, tempat, dan kronologi kejadiannya. Tentu ini merupakan sebuah masalah yang sampai saat ini masih menjadi fokus para pemerhati pendidikan sejarah. Secara pragmatis, masalah ini dapat diselesaikan dengan pembelajaran kreatif yang seringkali menjadi wacana andalan disetiap permasalahan dalam proses pembelajaran. Hanya saja, keberadaan guru sebagai fasilitator utama di dalam kelas seringkali belum optimal dalam menjalankan proses pembelajaran yang diinginkan.

Di dalam proses pembelajaran, keberadaan guru dituntut agar dapat menciptakan kegiatan belajar-mengajar yang kondusif, serta memberikan motivasi dan bimbingan agar peserta didik dapat mengembangkan potensi dan kreativitasnya melalui kegiatan belajar. Artinya, sebagai fasilitator guru tidak diarahkan untuk mendominasi jalannya pembelajaran, tetapi untuk menjembatani lahirnya potensi dan kreatifitas dari peserta didik itu sendiri. Hal ini sesuai dengan prinsip mengajar, bahwa tugas pendidik adalah memberikan kemudahan dan motivasi kepada peserta didik dalam pembelajaran (Sardiman, 2006: 2).

Berdasarkan pada hal di atas, banyak cara yang ditawarkan agar peserta didik dapat mengembangkan kreatifitasnya dalam pembelajaran. Berbagai inovasi pembelajaran yang lahir dari sintesis permasalahan yang berlangsung sedemikian kompleks dapat menjadi alternatif para guru di lapangan pendidikan. Tentu ini merupakan sebuah solusi yang baik atas permasalahan

yang dikemukakan di awal tulisan tadi. Namun secara teknis, muncul permasalahan baru, ketika para guru kurang update atau pun tidak begitu memahami berbagai alternatif pembelajaran yang ditawarkan sebelumnya. Untuk itu, maka dibutuhkan sebuah metode, agar pembelajaran kreatif 
yang diinginkan dapat diimplementasikan dengan baik dalam proses pembelajaran sejarah.

Penelitian Tindakan Kelas (PTK) adalah penelitian yang dilakukan oleh guru di dalam kelasnya sendiri melalui refleksi diri, dengan tujuan untuk memperbaiki kinerjanya sebagai guru, sehingga hasil belajar peserta didik menjadi meningkat. Melalui PTK, guru dapat melakukan uji coba terhadap berbagai bentuk pembelajaran kreatif di dalam kelas. Dalam proses PTK, guru dapat melakukan aksi-refleksi secara langsung dalam proses pembelajaran sejarah dan melakukan perbaikan secara berkala sampai hasil pembelajaran sesuai dengan target yang diinginkan.

Daryanto mengungkapkan ada empat manfaat PTK untuk guru, yaitu 1) Guru memiliki kemampuan untuk memperbaiki proses pembelajaran yang ia bawakan, melalui kajian mendalam kelas yang ia amati; 2) Guru dapat berkembang dan meningkatkan profesionalitas kerjanya melalui kegiatan menilai, merefleksi, dan perbaikan pembelajaran yang dirancangnya; 3) Guru mendapatkan kesempatan untuk berperan secara aktif mengembangkan pengetahuan dan keterampilannya sendiri; 4) Guru akan merasa lebih percaya diri, karena sering berlatih melakukan evaluasi diri, merefleksi diri, dan menganalisis kinerjanya di dalam kelas (Daryanto, 2011: 18).

Berbagai manfaat PTK di atas sejatinya dapat menyelesaikan berbagai persoalan yang dihadapi guru di lapangan. Namun demikian, kenyataannya masih ada sebagian guru yang belum mampu melaksanakan PTK dengan baik karena keterbatasan pengetahuan mulai dari analisis masalah, pelaksanaan, hingga pembuatan laporan PTK itu sendiri.

\section{METODE}

Kegiatan Pengabdian Kepada Masyarakat ini diadakan dalam bentuk penyuluhan dan pelatihan mengenai pembuatan laporan PTK bagi guru sejarah di Kota Palembang. Adapun jenis dan model kegiatan yang akan dilakukan dalam kegiatan pengabdian ini adalah sebagai berikut: (1) Jenis kegiatan yang akan dilakukan dalam kegiatan ini adalah penyuluhan dan pelatihan dalam rangka meningkatkan pengetahuan, pemahaman dan keterampilan bagi guru-guru sejarah tentang pembuatan laporan PTK; (2) Model kegiatan dalam pelaksanaan kegiatan pengabdian pada masyarakat ini adalah berupa pelatihan. Pelatihan ini diberikan dalam rangka menambah/memperdalam pengetahuan dan pemahaman para guru mengenai PTK; (3) Sifat kegiatan Kegiatan ini merupakan kegiatan penunjang dalam Tri Dharma Perguruan Tinggi bagi para guru sejarah SMA di Kota Palembang dalam pembuatan laporan PTK.

\section{Koordinasi dengan Guru Sejarah Kota Palembang}

Tim melakukan koordinasi dengan guru sejarah mengenai kegiatan pelatihan dan penyuluhan yang direncanakan, terutama mengenai jadwal dan tempat pelatihan, serta berbagai kelengkapan yang berkenaan dengan kegiatan.

\section{Introduksi PTK di Sekolah Menengah Atas}

Pada tahapan ini, tim memberikan pengenalan singkat mengenai konsep-konsep PTK, dimulai dari analisis situasi, pembuatan instrumen, pelaksanaan, evaluasi, hingga pembuatan laporan PTK. Pada tahap ini, tim juga memberikan contoh laporan PTK agar peserta lebih mudah memahami materi yang dimaksud.

\section{Penyampaian Materi-Materi}

Kegiatan selanjutnya adalah pembekalan peserta mengenai PTK. Tahapan ini penting untuk memancing kembali nalar peserta kegiatan mengenai PTK. Pada tahapan ini tim menyampaikan desain dan berbagai model siklus dari para pakar PTK seperti Kemmis dan Taggart, Elliot, Hopkin, Lewin dan lain-lain. Pada dasarnya PTK memiliki siklus yang dimulai dari perencanaan (plan), tindakan (act), pengamatan (observation), refleksi (reflection) dan seterusnya hingga data yang didapat berada di titik jenuh atau mencapai tahap saturasi.

\section{Jadwal Pelaksanaan Penyuluhan dan Pelatihan Pembuatan Laporan PTK}

Pelaksanaan Penyuluhan dan Pelatihan Pembuatan Laporan PTK diselenggarakan selama 3 hari, yaitu pada tanggal 26-28 September 2019 di SMA Srijaya Negara Kota Palembang. 


\section{HASIL DAN PEMBAHASAN}

Kegiatan pengabdian pada masyarakat didahului dengan kegiatan studi pendahuluan dengan cara melakukan diskusi kepada para alumni mengenai hal yang dibutuhkan dalam proses pembelajaran saat ini, khususnya alumni yang tergabung dalam Musyawarah Guru Mata Pelajaran (MGMP) Sejarah SMA dan Asosiai Guru Sejarah Indonesia (AGSI) Kota Palembang. Berdasarkan hasil diskusi, maka peneliti menyimpulkan bahwa para alumni meminta materi/bahan mengenai pembuatan proposal dan laporan Penelitian Tindakan Kelas untuk mendukung proses pembelajaran. Oleh karena itu, tim pengabdian mencoba untuk merancang kegiatan pelatihan dan penyusunan proposal dan laporan Penelitian Tindakan Kelas. Setelah proposal disetujui, tim pengabdian mulai mengundang guru-guru sejarah SMA di Kota Palembang untuk mengikuti kegiatan pengabdian pada masyarakat mengenai penyusunan laporan Penelitian Tindakan Kelas pada tanggal 26 -28 September 2019 yang bertempat di ruang kelas XII SMA Srijaya Negara Palembang. Kegiatan dilaksanakan mulai dari pukul 08.00-16.00 WIB.

\section{Pelaksanaan Penyuluhan dan Pelatihan Pembuatan Laporan PTK}

Kegiatan pengabdian dilaksanakan dengan beberapa sesi yang terdiri atas registrasi, pretest, penyampaian materi, dan posttest. Pada tahap awal untuk kelengkapan dokumentasi peserta diminta untuk melakukan registrasi terlebih dahulu dengan mengisi form yang sudah disediakan oleh tim pengabdian, yang terdiri atas data nama, asal sekolah, dan tanda tangan. Setelah semua peserta melakukan registrasi, tim pengabdian memberikan pretest kepada seluruh peserta pengabdian untuk mengetahui seberapa jauh pemahaman peserta terhadap materi yang akan disampaikan. Pelaksaan pretest dimulai pukul 08.15 - 08.45 WIB. Hasil pretest langsung diperiksa oleh tim pengabdian untuk diisampaikan hasilnya. Setelah melakukan pretest, peserta pengabdian dipersilahkan untuk break sejenak selama lima belas menit. Tepat pukul 09.00 WIB dilanjutkan dengan pemberian materi dari tim pengabdian. Penyampaian materi terdiri atas tiga sesi, yaitu gambaran umum Penelitian Tindakan Kelas, Implementasi Penelitian Tindakan Kelas dalam Pembelajaran Sejarah, dan pembuatan laporan Penelitian Tindakan Kelas.

Penyampaian materi yang pertama mengenai gambaran umum Penelitian Tindakan Kelas disampaikan oleh Dr. Hudaidah, M.Pd. Selanjutnya penyampaian materi mengenai Implementasi Penelitian Tindakan Kelas dalam Pembelajaran Sejarah oleh Muhammad Reza Pahlevi, M.Pd Materi selanjutnya adalah mengenai pembuatan laporan Penelitian Tindakan Kelas yang disampaikan oleh Dr. Hudaidah, M.Pd dan Muhammad Reza Pahlevi, M.Pd. Setelah materi, kegiatan dilanjutkan dengan langsung sesi tanya jawab.

Pada sesi tanya jawab, ada beberapa pertanyaan yang disampaikan oleh peserta diantaranya mengenai mengenai teknis pembuatan proposal Penelitian Tindakan Kelas yang masih belum terlalu jelas. Namun karena keterbatasan waktu, tim pengabdian menyarankan agar pemberian materi lanjutan mengenai pembuatan proposal Penelitian Tindakan Kelas akan dilakukan dengan melakukan pendampingan terhadap peserta secara langsung. Setelah sesi tanya jawab selesai, tim pengabdian memberikan posttest untuk mengetahui peningkatan pemahaman terhadap materi yang telah disampaikan. Setelah posttest selesai, ketua tim pengabdian Program Studi Pendidikan Sejarah menutup kegiatan pengabdian tepat pukul $16.00 \mathrm{WIB}$.

Selanjutnya, kegiatan dilaksanakan pada tanggal 27 September 2019 dengan melakukan pemantauan mengenai penyusunan proposal Penelitian Tindakan Kelas oleh peserta pengabdian. Pada kegiatan ini, peserta sudah sedikit banyak mengetahui mengenai bagaimana cara merancang proposal Penelitian Tindakan Kelas yang baik dan benar. Hal ini dikarenakan pada hari sebelumnya, peserta telah dibekali dengan materi yang disampaikan tim pengabdian Prodi Pendidikan Sejarah FKIP Unsri. Kegiatan pendampingan pembuatan proposal dilaksanakan dari pukul 08.00 WIB sampai waktu istirahat pukul 12.00 WIB. Kemudian dilanjutkan kembali pukul 13.30 WIB hingga pukul 16.00 WIB. Pendampingan pembuatan proposal Penelitian Tindakan Kelas berjalan lancar karena anggota tim pengabdian melakukan pendampingan secara intensif terhadap peserta pengabdian.

Pada hari berikutnya, Sabtu 28 September 2019, tim pengabdian Prodi Pendidikan Sejarah 
FKIP Unsri kembali melanjutkan kegiatan pendampingan pembuatan laporan Penelitian Tindakan Kelas. Pada hari ketiga ini, peserta meminta tim pengabdian untuk mengulangi materi

Mengenai pembuatan laporan Penelitian Tindakan Kelas. Hal ini dikarenakan sebagian peserta menganggap perlu agar materi tersebut diulangi. Setelah berdiskusi, tim pengabdian sepakat untuk mengulangi kembali materi mengenai pembuatan laporan Penelitian Tindakan Kelas. Setelah pemberian materi yang disampaikan oleh Dr. Hudaidah, M.Pd, kegiatan dilanjutkan dengan melakukan pendampingan pembuatan laporan Penelitian Tindakan Kelas. Kegiatan berlangsung dari pukul 09.00 WIB sampai waktu istirahat pukul 12.00 WIB. Kegiatan kembali dilanjutkan hingga pukul 15.00 WIB. Setelah itu, tim pengabdian memberikan post-test kepada peserta untuk mengetahui pemahaman peserta kegiatan pasca kegiatan pendampingan. Kegiatan ditutup pukul 15.45 WIB dengan memberikan tugas berupa perampungan proposal dan laporan yang akan dikumpulkan satu minggu setelah kegiatan.

\section{KESIMPULAN}

Sebagai seorang profesional, seorang guru hendaknya dapat lebih proaktif dalam menyelesaikan berbagai permasalahan dalam proses pembelajaran. Kurangnya kesadaran guru tersebut dapat menyebabkan pembelajaran sejarah menjadi kering dan mengurangi minat belajar peserta didik. Berdasar pada hal tersebut, maka penulis sepakat bahwa PTK dapat menjadi alternatif yang dirasa praktis, karena berkenaan langsung dengan proses pembelajaran di kelas. Demi memenuhi kebutuhan tersebut, maka diselenggarakanlah kegiatan penyuluhan dan pelatihan pembuatan laporan PTK bagi guru sejarah Sekolah Menengah Atas di Kota Palembang. Adapun hasil yang didapatkan dari kegiatan ini adalah:

Pertama, kegiatan penyuluhan dan pelatihan pembuatan laporan PTK bagi guru sejarah Sekolah Menengah Atas di Kota Palembang dapat berjalan dengan baik. Kedua, dengan pendampingan yang telah dilakukan secara intensif, para peserta sudah dapat menyusun laporan PTK yang baik dan sesuai dengan prosedur yang diinginkan. Ketiga, output PTK ini diharapkan dapat juga menjadi artikel ilmiah yang nantinya dapat berguna bagi para peserta guru.

Kesimpulan yang didapat dari kegiatan ini adalah bahwa kegiatan "Penyuluhan dan Pelatihan Pembuatan Laporan PTK bagi Guru Sejarah Sekolah Menengah Atas di Kota Palembang" ini memiliki manfaat yang sangat banyak, terutama bagi para guru sejarah yang tergabung dalam Musyawarah Guru Mata Pelajaran (MGMP) Sejarah Kota Palembang dan Asosiasi Guru Sejarah Indonesia (AGSI) cabang Kota Palembang. Selain itu, penulis berharap agar kegiatan ini dapat menjadi pemantik dalam menalar kembali sifat kritis para guru sejarah dalam melaksanakan proses pembelajaran di sekolah-sekolah.

\section{DAFTAR PUSTAKA}

Arikunto, Suharsimi. 2002. Penelitian Tindakan Kelas. Jakarta: Bumi Aksara.

Bloom, B.S, 1987. Taxonomy of Education Objectives. New York: Longman. Inc.

Daryanto, H.M. 2011. Administrasi Pendidikan. Jakarta. PT. Rineka Cipta.

Faciono, Peter A. 2011 Anderson, LW and Krathwohl. 1995. A Txonomy for Learning, Teaching, and Assessing: A Revition of Bloom's Taxonomy of Educational Objectives. New York: Addison Wesley Longman.

Hermawan, dkk. 2010. Pengembang Kurikulum dan Pembelajaran di SD. Jakarta : UT

Loeloek. 2013. Panduan Memahami Kurikulum Nasional. Jakarta: Pustakakarya

Mangunwijaya. 2013. Menyambut Kurikulum Nasional.Forum VII. Jakarta: Kompas

Mulyasa. 2009. Menjadi Guru Profesional Menciftakan Pembelajaran Kreatif dan Menyenangkan. Bandung: Rosdakarya.

Mulyasa. 2013. Pengembangan Implementasi Kurikulum Nasional. Bandung: Rosdakarya

Munawaroh, Ishiatun. TT. Pengembangan Model Pembelajaran Tematik Untuk Mengembangan Keterampilan Berpikir Kritis Siswa SD Kelas Rendah. UNY:FIP.

Sanjaya, Wina. 2016. Penelitian Tindakan Kelas. Prenada Media. hlm. 22.

Muzamairoh. 2013. Kupas Tuntas Kurikulum Nasional. Jakarta: Kata Pena 
Narmoatmojo, Winarno. 2010. Pendidikan Karakter di Indonesia Dalam Persfektif Filsafat Moral dan Filsafat Pendidikan.

Narmoatmojo, Winarno, 2010. Pendidikan Nilai di Era Global. Unisri: Surakarta . diakses Juni 2011.

Rusman. 2011. Model-Model Pembelajaran Mengembangkan Profesionalisme Guru. Jakarta: Rajawali Pers.

Sagala Syaiful dan Syawal Gultom, 2011, Praktik Kerja Pendidikan di seluruh wilayah, Bandung:Alfabeta

Sholeh, Asrotun. 2006. Membangun Profesional Guru. Jakarta: Elsa

Suyatno. 2009. Menjelajah Pembelajaran Inovatif. Sidoarjo: Masmedia Buana Pustaka.

Trianto. 2007. Model-Model Pembelajaran Inovatif Berorientasi Konstruktivis. Jakarta: Prestasi Pustaka.

Undang-Undang RI No. 20 Tahun 2003. Tentang Sisdiknas. Bandung:Citra Umbara.

Usman, Uzer. 2009. Menjadi Guru Profesional. Bandung: Rosdakarya.

Zainal, Arifin. 2010. Konsep dan Model Pengembangan Kurikulum. Bandung: Rosdakarya.

Woolfolk, Anita. 2004. Educational Psychology. Ohio: Pearson. 